\title{
Velkommen til et nyt Udenrigs
}

Udenrigs udkommer med dette nummer i et nyt design som led i en gradvis modernisering af tidsskriftet, der vil fortsætte resten af året.

Denne gang er hovedvægten i fornyelsen lagt på det grafiske udseende, bl.a. med indførelse af billeder, samt en ny klumme, som fremover bliver et fast element. I de følgende numre vil vi eksperimentere med artikelformerne, så der bliver større variation mellem genrerne.

Én ting røres der ikke ved: den grundige og nuancerede orientering på højt niveau om aktuelle udenrigspolitiske og internationale emner. Målet om at bibringe læserne ny viden og indsigt vil blive fastholdt.

Valget til Europa-Parlamentet står for døren. Derfor fokuserer vi i et tema i dette nummer på EU's udvikling og Danmarks placering i et Europa under forandring med bidrag fra bl.a. Martin Lidegaard, Connie Hedegaard, Uffe Østergaard og Christine Nissen.

Flere af bidragene er redigerede versioner af indlæg på en stor EU-konference, som Det Udenrigspolitiske Selskab arrangerede i marts sammen med bl.a. Københavns Universitet. Konferencen blev støttet af Europa-Nævnet.

Krisen om Ukraine har domineret overskrifterne i vinteren og foråret 2014. Vi analyserer udviklingen i fire baggrundsartikler med bidrag fra Vibeke Sperling, Ib Faurby, Ole Bang Nielsen og Peder Munk Jensen.

Skotland går til folkeafstemning til september om uafhængighed eller fortsat tilknytning til England, Wales og Nordirland. Henrik Larsen trækker fronterne op.

Endelig tages den hidtil mest omtalte udenrigspolitiske udgivelse på dansk i år, Bent Jensens bog om Danmark under Den Kolde Krig, under behandling i en stor anmeldelse af Ib Faurby.

\section{Velkommen til et nyt Udenrigs!}

